\title{
Free Economic Zones from the Legal Perspective in Kosovo
}

\author{
Dr.Sc. Armand Krasniqi, Prof. Assoc. \\ University of Prishtina "Hasan Prishtina", Economic Faculty, Prishtina, Kosovo \\ armand.krasniqi@uni-pr.edu \\ Mr.Sc. Diamanta Sojeva. Ass \\ University of Prishtina "Hasan Prishtina", Economic Faculty, Prishtina, Kosovo \\ diamanta.sojeva@uni-pr.edu
}

Doi:10.5901/ajis.2015.v4n2s1p14

\begin{abstract}
The role and the positive effects that economic zones create in the contemporary world are great. That their establishment and their activities have proven to be a success story is not a matter of dispute. Countries in transition find themselves before serious challenges in order to find ways for economic development, promoting employment, issuing legislation and adapting such legislation to the criteria of EU Acquis Communautaire, which must guarantee above all the application of political visions, without undermining competition. What the state institutions have not made clear enough is the form and content of these economic zones. In fact the general public perception is that through such free economic zones the country's economy will be liberalized and favorable conditions for integration will be created, which is not entirely realistic. The creation of such free economic zones initially enables the establishment of certain economic activities within a location of the country. Kosovo has managed to establish a relatively adequate legal framework for free economic zones, where some such zones have already been created, however it is still far from the modern concept of their establishment and function. In our opinion the creation of free economic zones in Kosovo, which as a country faces an extremely weak economy in all of its segments, is not considered a wise and a proper government decision. Nevertheless, if the policy makers deem this to be realistic, then the situation should be regulated by amending a series of primary legal acts that specify the potential incentive measures in relation to tax and customs regime, including customs duties, taxes of all kinds, and excise duties.
\end{abstract}

Keywords: law, free zone, economy, customs, institution

\section{Introduction}

The Republic of Kosovo, at least thus far, is in no way giving indications of hope that is working its way out of a deep crisis of socio-economic stagnation. Unfortunately, official information emerging from relevant institutions provide alarming data concerning the low economic growth rate, low number of employees, the prevalence of informal economy, reduction of up to $50 \%$ in foreign direct investment per year, and so on. (http://koha.net/?id=27\&/=18303). On the other hand, the country's legislative framework, largely formally, has been completed, but in its current state it is completely non-functional and difficult to implement. This is do to the imbalance of the legal system with the level of social development and with the economic development strategy. Surprisingly, this situation is not reflected upon at all by competent institutions! And this is not all; so much is being propagated on the economic development perspective that it has managed to put in motion the parliamentary mechanism in order to promulgate laws, perhaps for political consumption and promotion, but which are ultimately only listed in the country's legal database.

The best case to argue this situation is the propagation and adoption of the law on free economic zones in the country in early 2013 (http://kuvendikosoves.org/common/docs/ligjet/). Through this law, our government claims that businesses, i.e. business operators, are placed in a special area with better conditions compared to other parts of Kosovo. The concept of these areas has been designed with the intention to develop certain economic activities, accompanied with easy access to transport, energy, water and other essential businesses services. Based on the experience of developed countries, the operation of such economic zones has been an important element in the overall development of the country. And this practice should be useful for Kosovo as well. However, besides establishing the legal basis for the creation of economic zones, the actual operation of such zones in Kosovo does not appear to be successful so far. Since the entry into force of the Law on Economic Zones, the Kosovo government has announced only 
two areas as economic zones, namely: the Business Park in Drenas and the Technological Park in Skenderaj, the latter having completely failed as a project. On the other hand, in six other municipalities in Kosovo, business parks or business incubators have been created, but none yet have been declared as an economic zone by the Government (http://www.institutigap.org/documents/37812_ZonatEkonomike.pdf)

The lack of a national economic development strategy, as an umbrella document covering a synchronized development, and the lack of other relevant sub-strategies, have allowed for single opportunities for certain individuals or other groups to promote "hope" or ad-hoc policies, which in fact result in non-functional legislation. This is a typical characteristic of non-serious state institutions that is best illustrated in Kosovo.

\section{The Modern Concept of Free Economic Zones}

According to modern concepts, the notion of free economic zones is defined by limited spaces that are characterized by specific conditions, with special benefits such as exemption from payment of customs duties, exemptions from the obligation to calculate and pay value added tax, and may have various functions, depending on certain political and military objectives. A Free Zone, often depending on its nature may be called a special free economic zone, is an area in which, under favorable conditions, enables the supply, storage, industrial production and processing of goods (http://www.thedti.gov.za/industrial_development/sez.jsp, last visited on 01.04.2015).

Free economic zones are part of a state territory, defined specifically and physically marked where they are to enable various activities that stimulate business and apply special regime that mainly reflects the preferential tariff treatment, tax exemptions and simplified administrative procedures. Free Zones include specific areas with special conditions, with a special economic regime covering significant benefits, allowances and incentives to produce goods that are mainly intended for export (Paul, R. "Economic Freedom Zone").

Free zones are the centers that integrate all services in one place - services concerning production, storage, loading and unloading, packaging, shipping, freight shipping services, banking, customs and other administrative tasks (Paul , R. "Economic Freedom Zone").

In the aspect of legal subjectivity, a free zone is a legal entity and, based on the legislation covering business organizations, is has its steering bodies (apart from the founders). These entities provide services of common interest to all users by performing technical, administrative, and professional tasks related to the ongoing activities within the zone. In accordance with the conditions to provide services within the zone, they independently and concisely perform specific activities that uphold the prescribed measures for special protection of life and working environment in the area.

Business practices have proven that free zones are profitable institutions specifically for business development. Economic and administrative reasons for the existence of free zones, allowing them profitability, are reflected in the fact that they enable savings in various areas, such as: customs (exemption from payment or late payment), fees, taxes or other measures and decisions of economic nature. Another reason for the existence of free zones is the concentration of services and requirements in one place. They represent a logistics center for freight shipping, customs, storage, processing, transport, etc.

Free zones are intended to significantly encourage and promote investment in the economy of a country. Thus, within the free zone of economic activity, export activities are encouraged and in this sense the growth of foreign trade of the country is stimulated, ultimately achieving a range of indirect positive effects on the local economy. Furthermore, the motives of foreign investment partners in the free zone should be supported by effective legal regulations that ensure legislative stability and above all, a safety blanket for the functioning of the business.

The success of a free zone depends mainly on economic objectives and instruments. The policies of the host country and the role of the state in this regard depend on how such policies are designed, developed and implemented. Development and advancement of free zones is based on a clear definition of a country's economic policy and legislation that is oriented in attracting foreign investors to this zone. In addition, adaptation of the zone should be considered based on the procedures and benefits set by the state authorities as well as the overall business environment in the country.

As a general rule, the founders of the free zone may be the founders of a company on managing the zone. According to most theorists and researchers from the economics sciences covering free economic zones, attribute special considerations to this business form with regard to assessment of the expected effects on the investment, especially in terms of production of goods and provision of services, employment and technology transfer, stating the activities to be carried out in the zone. The founders of the free zone must provide proof that they are in possession, are renting, or in any way have the right to use the land on which the free zone is to be established. We have received the opinion of the local government pertaining to the justification for the establishment of zones. 


\section{The Current Legislative Framework Regulating Free Economic Zones}

The legislative framework on the free economic zones in the Republic of Kosovo consists mainly of the following laws and legal acts, namely: the Law on Economic Zones (Law on Economic Zones no. 04 / L-159) that formally regulates the establishment, operation, supervision and development of economic zones, the rights and obligations of developers, managing operators, users functioning within them, types of activities performed there, as well as the form to determine the location on economic zones. Establishing economic zones intends to help economic development in the country, particularly the private sector, by encouraging investment, opening new jobs, attracting advanced technologies, increasing competitiveness among local businesses, etc. According to the law in question, the right to initiate the establishment of the economic zone lies with the Municipal Assembly, the business community, public-private partnerships and MTI itself, provided that the construction of the zone is funded from the Kosovo budget. And, if all conditions are met for the establishment of the economic zone, it is the Government of Kosovo, which issues a decision to declare an area as an Economic Zone, consequently defining the status of the zone (economic / industrial, industrial park / technology), the zone boundaries, types of activities, the way the zone is outsourced (lease or concession), etc. (Law on Economic Zones no. 04 / L-159).

The Administrative Instruction on the establishment of the Economic Zones Unit (Administrative Instruction no. 2009/14, taken from http://www.mti-ks.org/sq/Udhezimet-Administrative) defines the organization, scope, and functioning of the Unit for the Economic Zones. This Unit operates within the Agency for the Support of Small and Medium size Enterprises (SMEs) within the Ministry of Trade and Industry. The economic zones Unit is responsible for developing policies and plans on the establishment of economic zones, their operation, management etc.

The Administrative Instruction on the Procedure of Application and Criteria of Obtaining the Decision by the Developer, (Administrative Instruction no. 2009/23, taken from http://www.mti-ks.org/sq/Udhezimet-Administrative) that defines application procedures and criteria that must be met by the initiator before obtaining a decision to establish an Economic Zone. According to this document, there are a total of 11 procedures and 8 approvals from the relevant ministries which need to be obtained before receiving permission to create an Economic Zone:

Administrative Instruction on the relations of the responsible institutions, zone developers and other institutions (Administrative Instruction no. 2009/24, taken from http://www.mti-ks.org/sq/Udhezimet-Administrative) regulates the relationship between the parties by defining the duties of each of them and simultaneously obliging them to maintain constant contact on all matters related to the Economic Zone.

Administrative Instruction on the control procedures of Economic Zones (Administrative Instruction no. 2009/25, taken from http://www.mti-ks.org/sq/Udhezimet-Administrative) defines the procedures and actions taken on the supervision and control of economic zones. According to this document, if the economic zone developer does not respect the rules set by the contract, the Agency for the Promotion of SMEs gives written notice and a period of 60 days to improve the irregularities. If after 60 days the developer has not improved the situation, then the Agency initiates the procedure for amending the decision, giving a 24-hour deadline for the cessation of activities by the user.

Administrative Instruction on the form, content, validity and fee on issuing a decision (Administrative Instruction no. 2009/26, taken from http://www.mti-ks.org/sq/Udhezimet-Administrative). This decision is issued by the defining institution and contains the criteria that are defined by the Administrative Instruction.

Administrative Instruction on the procedure, form and content of the competition, conditions and criteria for the establishment of business entities in economic zones (Administrative Instruction Nr. 03/2014: taken from http://www.mtiks.org/sq/Udhezimet-Administrative).

Administrative instruction no. 01/2014 on setting out the procedure on submitting the application to obtain permission, its proceeding and granting the permission, and the content of the registry of economic zones (Administrative Instruction Nr. 01/2014: taken from http://www.mti-ks.org/sq/Udhezimet-Administrative)

Administrative Instruction No.17/2013 on the manner of establishing and functioning of business incubators (Administrative Instruction Nr. 17/2013: taken from http://www.mti-ks.org/sq/Udhezimet-Administrative).

Generally, economic zones are recognized as business parks, industrial parks or technology parks respectively. Meanwhile, inside and outside such parks there are also business incubators, which are aimed at gathering small and medium enterprises in a single facility.

In analyzing the above-listed acts, one can conclude that all of them have to do with the internal regulation of the free economic zone, including the responsibilities of the economic operators functioning within. Hoever, these acts are not sufficient for a normal operation since they clearly do not regulate the issue of tax, customs and other preferences (incentives). 
It should be noted, that the economic zones based the Law on Economic Zones and the sub-legal acts listed above, specifically the economic entities operating within these zones currently enjoy only incentives in terms of utilities (electricity, water, telephone, internet), low rent, etc., but in no way the waiver/delay of payment of import duties and the suspension of implementation of the trade policies in the case of importation of goods, with an exception of certain entities authorized as a Customs Warehouse by Kosovo Customs.

Kosovo customs have not been granted permission to enforce a government decision on establishing free economic zones in Gjakova and Mitrovica. Despite this situation, referring to the Customs and Excise Code (Customs and Excise Code of Kosovo, no. 03/L-109 specifically - Articles 165-179 and Articles 376 -387) and Administrative Instruction 11/2009 on implementation of the Customs and Excise Code (Administrative Instruction 11/2009; taken from http://www.mti-ks.org/sq/Udhezimet-Administrative) there is sufficient basis to cover the legal aspect for the operation of the free customs zones/warehouses.

Realistically speaking, the Customs and Excise Code, as a general legal act, is not adequate to specifically regulate the customs regime in the economic zones. Despite this, if changes and amendments to this code are not undertaken, then it is necessary to issue another sub-legal act that would set the necessary conditions on authorization and other matters that should be the subject of customs supervision. Specially, it should clarify the aspect of the territorial and functional operation of the economic zone, considering the fact that paragraph 3 of article 166 stipulates that "free zones, except those specified in Article 168, shall be enclosed" (For more see The Customs and Excise Code of Kosovo, no. 03/L-109, Chapter III, dedicated to "other types of customs-approved treatment or use, section on free zones and free warehouses").

So far, despite the existence of free economic zones, Kosovo Customs, at least formally, considers that no such area exists in the country and that there is no environment or proper authorization approved for a free zone or free warehouse as stipulated under Article 166 of the Customs and Excise Code and (Law no. 04 / L-159 because the law, except for Economic Zones, it also speaks about free zones and free warehouses). Moreover, pursuant to paragraph 1 of Article 165 of the Customs and Excise Code of Kosovo, Free zones and free warehouses shall be parts of Kosovo or premises situated within Kosovo and separated from the rest of it, in which: a) Non-Kosovo goods are considered, for the purpose of import duties and commercial policy import measures, as not being within Kosovo, provided they are not released for free circulation or placed under another customs procedure or used or consumed under conditions other than those provided for in the customs legislation (for more see Customs and Excise Code of Kosovo, no. 03/L-109, Chapter III, on "other types of customs-approved treatment or use, section Free zones and free warehouses").

Also, Article 166 paragraph 1, stipulates that the Government of the Republic of Kosovo, in consultation with the Customs, may designate parts of Kosovo as free zones or authorize the establishment of free warehouses, whereas paragraph 2 of that Article, specifies that the Government of the Republic of Kosovo, in consultation with the Customs, shall determine the area covered by each zone. Premises to be designated as free warehouses must be approved by the Customs (for more see Customs and Excise Code of Kosovo, no. 03/L-109, Chapter III, on "other types of customsapproved treatment or use, section Free zones and free warehouses").

Until now, the country's government, with respect to the findings above, has not taken any decision or has not sent any request to the Kosovo Customs to act in this regard.

\section{Regulation of Free Economic Zones}

Based the best practices of developed countries on the creation and effective functioning of free economic zones, it is evident that above all, they should be established in accordance with the instructions of customs authorities. This is true because it is exactly this institution which enforces customs authority and control in order to prevent irregular circulation of any goods in a free zone inside or outside. For the implementation of customs controls in the free zone, a competent customs authority bust be established that has territorial jurisdiction over the area or the free zone. Goods that are brought in and out of the area, and goods stored in the area, should be placed under customs supervision and control. These measures are implemented in accordance with the provisions of the Customs Code governing customs system and customs procedures. If this is achieved, then foreign and domestic goods can enter and be stored in the free zone.

Storage of goods in the free zone should not be limited in terms of time. Domestic goods intended for export, located in a free zone, an application should be filled out in accordance with a specific regulation defining the storage time limitations. All goods entering or leaving a free zone should be reported to the customs supervision and control service through the filing of documents in compliance with transport procedures.

A user may acquire goods from the area and they can carry them out in another part of the territory of the Republic 
of Kosovo or bring goods into the area from the rest of the territory of Kosovo for the purpose of putting them in the procedure for processing, reviewing, testing, repairing or presentation through promotion. The customs authority may inspect the goods and implement other customs control over goods entering, leaving or remaining in a free zone in accordance with the criteria established on the basis of a system for analyzing and assessing risk, or whenever it is suspected that this does not comply with customs regulations for operation in the free zone.

The user of the zone shall, for customs supervision, maintain data in a certain way for entry into a free zone and removal of goods from it, including the use and change of goods. A user is obliged, before commencing operations in the free zone, to present an application for approval of the form and content of the records of foreign goods in the free zone to the relevant customs authorities. If the user intends to enter the zone with local goods, they must provide a written request for approving the form and content of the records of local goods in the free zone.

\section{Amend the Systemic Laws}

The legislative framework for free zones in the country should be supplemented and amended in order to regulate this modern economic activity. Despite the economic rationale and effectiveness of their role, for which we have quite a few reservations, the situation in which we are currently needs to be regulated. The competent institutions, in order to make these zones operational, should come up with a legal plan to provide financial incentives, namely providing exemption opportunities from certain taxes for a certain period of time. Initially, $50 \%$ exemption from taxation for local workers for at least the first 5 years; Providing non-financial incentive, meaning easier access to necessary services, such as: electricity, fuels, continuous water supply, easy and quick access to the airport, railway, highway, etc. Furthermore, such incentives may include creating opportunities for easier access to investment capital financing, whether through the provision of loans with favorable conditions, through provision of the legal basis for the establishment of investment companies ("Business angels") or through creating a financial institution for business development.

Another possibility could be the increase of funds for the SME Promotion Agency, which would provide start-up capital investment based on previously defined criteria (number of employees, capital investment by the investing company, etc.). Furthermore, urgent consideration should be given to the specialization of economic zones, i.e. the Dukagjini region should be specialized for agricultural investors, Gjakova region for the textile industry, Peja region for tourism, craft, etc., Pristina region to technology investors and so on. Dialogue mechanisms should be stimulated, considering zoning opportunities by private or public developers or public-private partnerships. An important segment is to facilitate bureaucratic procedures and the large number of documents required for applying for an economic zone. Supplementing and amending the law with respect to the current legal deficiencies, specifically stipulating action if an economic zone developer does not meet all the necessary documentation. Punitive measures and timeframes should be made clear. The government urgently needs to take steps to improve communication between the key stakeholders for the development of economic zones.

The Ministry of Trade and Industry should develop a strategy on promoting the new law, because many businesses have not been informed about the benefits offered by such zones.

\section{Conclusions with Recommendations}

The role of free zones in the world economy is gaining in importance day by day. Kosovo has a partially suitable legislative framework for the economic zones, which formally regulates the establishment, operation, supervision and development of economic zones, the rights and obligations of developers, managing operators, users functioning within them, types of activities carried out within them and the manner to determine the location of economic zones. This framework aims to regulate and facilitate economic development in the country through the establishment of free economic zones and, through them, to promote investment, open new job opportunities, attract advanced technologies, increase the competition among local businesses, etc. Despite the existing legal basis, the results and effects that the free economic zones have produced are not what were originally expected. For this reason, in all areas of academic and economic life, now is the right time to seriously raise the issue related to free economic zones.

Initially, the effectiveness and rationality of these zones will certainly need to be considered rationally and wisely on the basis of experiences from other countries that are well-known for this segment. The rationale for their existence should be treated as part of a national strategy for business development in the transition process, which includes the positioning of the free zones in the country according to the terms that are required by international trade criteria. There is no dilemma that the process of creation of free economic zones is defined and regulated by the legislative framework for 
free zones only after certain procedures are undertaken by the competent institutions of the Government of the Republic of Kosovo. The country has currently established a total of 10 free economic zones in total 8 different municipalities of Kosovo. In the municipalities they are known as business parks, industrial parks or as business incubators. Free economic zones are currently not allocated on the basis of specific activities. Within such a zone there are different operating businesses, which, by the nature of their activity, should not be near to each other. As such, within a zone one may find a propane-butane storage facility and a nursery, it has growers of vegetables and metal processors. The paper gave answers to the question whether there is a a free zone or free warehouse in Kosovo based on the customs legislation? The correct answer is that the Government of the Republic of Kosovo has declared no area, nor has it given any authorization to approve an area as a free zone or free warehouse within the meaning of Article 166 of the Kosovo Customs and Excise Law (Law no. 04/L-159, because the law, in addition to treating economic zones, also mentions free zones and free warehouses). From this emerges the clear fact that, despite the current legislation in place, in reality we have no free economic zones in the modern sense of meaning and content.

In dealing with this subject, it became obvious that legislation must be able to warrant the provision of financial incentives, specifically to create opportunities for tax exemptions in doing business in the economic zones, provision of non-financial incentives to enable easier access to required services, easier access to investment capital financing, whether through the provision of loans with favorable conditions, preparing the legal basis for the establishment of investment companies or a financial institution that fosters business development. In the terms and conditions of our country, it would be worth if the conditions are created for specialized economic zones, along with continuously building dialogue mechanisms, namely providing opportunities to create zones by private developers, public developers, or publicprivate ones, and followed by the reduction of bureaucratic procedures that require a large number of documents in applying for the economic zone.

\section{References}

Paul, R. " Economic Freedom Zones", http://www.paul.senate.gov/files/documents/EconomicFreedomZones.pdf

Palmioli, G. \& Adam Heal" Structural Economic Reform in China: The Role of the Shanghai Free Trade Zone" ISSUE No. 3, November 2014 ,

http://www.unescap.org/sites/default/files/Trade\%20Insights\%20-\%20lssue\%20No.\%203.pdf 2. Legislation

Law on Economic Zones No. 04/L-159

Kosovo Customs and Excise Code Nr. 03/L - 109

Administrative Instruction No. 2009/14: taken from http://www.mti-ks.org/sq/

Administrative Instruction No. 2009/23: taken from http://www.mti-ks.org/sq/

Administrative Instruction No. 2009/24: taken from http://www.mti-ks.org/sq/

Administrative Instruction No. 2009/25: taken from http://www.mti-ks.org/sq/

Administrative Instruction No. 2009/26: taken from http://www.mti-ks.org/sq/

Administrative Instruction No. 03/2014: taken from http://www.mti-ks.org/sq/

Administrative Instruction No. 01/2014: taken from http://www.mti-ks.org/sq/

Administrative Instruction No. 17/2013: taken from http://www.mti-ks.org/sq/

GAP Institute "Policy Analysis "Law on Economic Zones: its impact in the development of business parks" May 2012, taken from http://www.institutigap.org/documents/37812_ZonatEkonomike.pdf

http://www.thedti.gov.za/industrial_development/sez.jsp, last visited on 01.04.2015

Program on managing economic zones in Kosovo, Government of Kosovo - Ministry of Trade and Industry Research conducted by the University for Business and Technology UBT on behalf of the Agency for Supporting Small and Medium Enterprises within the Ministry of Trade and Industry. Taken from: http://www.zonatekonomike.org/repository/docs/Programi_per_menaxhimin_e_ Zonave_Ekonomike_60282..pdf; 